\title{
Digital Government and Sustainable Development
}

\author{
Conceição Castro $^{1}$ (D) Cristina Lopes ${ }^{2}$ (D)
}

Received: 26 February 2020 / Accepted: 19 January 2021 / Published online: 20 February 2021

(c) The Author(s), under exclusive licence to Springer Science+Business Media, LLC part of Springer Nature 2021

\begin{abstract}
Sustainable development is a concern and a challenge of modern societies, either in developing and developed countries. Good governance is crucial to managing efficiently all kind of resources, including natural resources, for the well-being of current and future generations. Digital transformation can be a key driver of changes in governments if they want to enhance transparency, accountability and efficiency. E-government facilitates integrated policies and public services to promote sustainable and inclusive economic growth, social development and environmental protection. E-government contributes to efficient resource management, and so can help to improve namely natural resource usage in the present to avoid damage to their usage in the future.

The aim of this study is to analyse the impact of e-government on sustainable development. Using a logit model, for a sample of 103 countries in the period 20032018, the results suggest that e-government development is a positive determinant for a country to attain sustainable development, proxied by adjusted net savings, that embraces a country's economic, social and environmental development. This study provides evidence that e-government increases the probability to attain sustainable development mostly in developing and transition economies.

The results also suggest that economic growth and gross national income per capita are significant positive influences in sustainable development in the whole sample and that countries with lower age dependency and natural resource rents are more likely to have sustainable development.

Developing e-government allows promoting sustainable development, particularly in developing and in transition economies.
\end{abstract}

Keywords Sustainable development $\cdot$ E-government $\cdot$ Adjusted net savings $\cdot$ Natural resources

Conceição Castro

mariacastro@iscap.ipp.pt

Extended author information available on the last page of the article 


\section{Introduction}

Economies have experienced strong economic growth in the last century with the consequently social and environmental impacts, which challenge the well-being of current and future generations. Policies begin to change the focus from economic growth to the need to balance this growth with social and environmental concerns. Sustainable development adds to the economic growth the concern with greening the national accounts, by including the depletion of natural capital (Pardi et al., 2015). The United Nations World Commission on Environment and Development Sustainable (1987, 17), in its report "Our Common Future", included the well-known definition of sustainable development, as the "development that meets the needs of the present without compromising the ability of future generations to meet their own needs". This new orientation raised the question of measuring sustainable development and several indicators emerged. One of the indicators of sustainability which is most accepted in literature (Arrow et al., 2003; Boos, 2015; Koirala \& Pradhan, 2019) is the adjusted net savings calculated by the World Bank. The adjusted net savings measures the "true rate of savings in an economy after taking into account investments in human capital, depletion of natural resources and damage caused by pollution" (World Bank, 2012, 1). According to the World Bank (2020), this indicator for sustainable development was designed based on the economic theory that savings equal investment and this is a measure of the change in wealth. Changes in wealth are linked to the sustainability of development since if a country is depleting its assets, it is not in a sustainable path (World Bank, 2006). Adjusted net savings embrace a country's economic, social and environmental development.

Previous research recognized that the quality of institutions is crucial for sustainable development (Aidt, 2010; Boos \& Holm-Müller, 2013; Bota-Avram et al., 2018; Sato et al., 2018; United Nations, 2018; Uwasu \& Yabar, 2011), since this requires a "set of institutions that are capable of managing the natural resources, collecting resource rents and directing these rents into profitable investments" (World Bank, 2006, xx). Several authors consider that resource curse is mainly driven by poor quality of governance (Acemoglu \& Robinson, 2012; Aidt, 2010; Hanley et al., 2015; Van der Ploeg, 2011) and good governance can contribute to proper resource allocation, which results in higher performance of sustainable development (Güney, 2017a; Sato et al., 2018). The success of sustainable development depends on the commitment of the stakeholders. Sustainable development is "the eras of "e", hardware, software, service and people" (Bawazir, 2006, 1).

With the digital revolution, the use of information and communication technologies (ICTs) by governments, either in developed and developing countries (AdjeiBamfo et al., 2019), facilitates integrated policies and public services and promotes strong and transparent institutions contributing to attaining sustainable development (United Nations, 2016). Advances in ICTs have opened opportunities to transform the relationship between government and citizens, contributing to the goals of better government, which is crucial for sustainable development. E-government contributes to the efficient management of resources, and so can help to improve natural resource usage in the present to avoid damage to natural resource usage in the future. 
Previous literature highlights the importance of e-government to promote transparency, participation and accountability (Corojan \& Criado, 2012; Dwivedi et al., 2009; Elbahnasawy, 2014; Gautam et al., 2017; Klitgaard, 1988; Srivastava et al., 2016; Sunday, 2014) and the favourable effects on economic growth (Khan \& Majeed, 2019; Majeed \& Malik, 2016).

Nevertheless, to the authors' best knowledge, there are no previous studies analysing the impact of e-government on sustainable development, measured by the adjusted net savings, with panel data. To fill this gap in economic literature, the objective of this paper is to analyse the effects of e-government development in sustainable development.

\section{Literature Review}

\section{Sustainable Development and the Adjusted Net Savings}

The need to balance economic growth with social and environmental concerns requires to be measured by other indicators than GDP growth. Although the underlying perspective is that economic growth will guide to higher levels of welfare and quality of life, this is not enough to measure the progress of economic welfare and sustainable development (Bota-Avram et al., 2018). Sustainability must be analysed from different perspectives, the main ones being the economic, social and environmental dimensions (Rutherford, 1997). Also, Hardi et al. (1997) suggested that definitions of sustainability should incorporate economic and ecological aspects, along with human well-being. In economic terms, the problem of sustainability concerns the maintenance of capital in all its forms, and that humankind must preserve capital for future generations (Van Bellen, 2010). By integrating natural capital as one of the capital forms, the economic perspective approaches the environmental one through the concepts of strong and weak sustainability, although in both, humankind must preserve it for future generations. Weak sustainability is based on the Hartwick Rule according to which the income from the exploitation of natural resources should be reinvested in other forms of capital in order to maintain total wealth and to accomplish non-declining well-being over time (Hartwick, 1977, 1990). Weak sustainability assumes that all forms of capital are substitutes and there are no significant differences between the kinds of well-being they generate (Ekins et al., 2003; Neumayer, 2012, 2013), and it is the overall stock maintenance, at least, that matters (Pelenc et al., 2015). In strong sustainability, natural capital is not seen as a simple stock of resources, since it is "a set of complex systems consisting of evolving biotic and abiotic elements that interact in ways that determine the ecosystem's capacity to provide human society directly and/or indirectly with a wide array of functions and services" (Pelenc et al., 2015, 1). So, there is a critical nature capital (Pearce et al., 1989) for which there are no substitutes. In this perspective, sustainable development requires the preservation of this critical natural capital to provide the services that are fundamental for well-being (Brand, 2009; Chiesura \& De Groot, 2003; De Groot et al., 2003; Dietz \& Neumayer, 2007; Ekins et al., 2003; Noël \& O'Connor, 1998) and cannot be accomplished by re-investing income from the depletion of natural resources into physical and human capital (Boos, 2015). While in 
weak sustainability if the net investment in all forms of capital is positive, the economy has a positive capacity to provide future utility (Boos, 2015); in strong sustainability, it is necessary to conserve the natural capital at a critical level for the well-being of future generations.

It was necessary to develop indicators considering the economic, social and environmental dimensions (Van Bellen, 2010). The multifaceted and complexity of the concept of sustainable development resulted in the development of several indicators, but some of them do not reflect all the dimensions of sustainable development (Witulski and Dias 2020). In literature, one of the indicators most used is the adjusted net savings (or Genuine Savings) from the World Bank (Arrow et al., 2003; Boos, 2015; Bota-Avram et al., 2018; Everett \& Wilks, 1999; Qasim \& Grimes, 2018; Koirala \& Pradhan, 2019), following the capital approach, that measures the change in the value of a set of assets, excluding capital gains. It is an indicator of weak sustainability and embraces the economic, social and environmental dimensions of sustainability. There are other indicators such as the Human Development Index (HDI) that includes aspects of human development, such as education, long life and the standard of living, and so covers the economic and social dimensions of sustainable development but does not account for environmental degradation. The Environmental Performance Index only covers environment issues. The Sustainable Society Index covers the three dimensions of sustainability, but there is not an aggregation of the dimensions into an overall index, following the recommendations of Joint Research Centre (JRC) of the European Commission due to the negative correlation between the human and environmental well-being dimensions, and is only published every 2 years. Others are calculated only for few countries (Commitment to Development Index, Index for Sustainable Economic Welfare), among others.

Adjusted net savings from the World Bank is commonly adopted as a broad indicator to measure sustainability over the long run (Arrow et al., 2003; Hanley et al., 2015; Qasim \& Grimes, 2018). The adjusted net savings (ANS) is obtained from the gross national saving (GNS) by making the following adjustments:

(1) the consumption of produced capital is deducted to obtain net national saving $\left(D_{\mathrm{K}}\right)$

(2) the government current operational expenditure in education is added to take into account the investment in human capital (GEE);

(3) the depletion of natural capital (energy, mineral and net forest) is deducted to express the decline in asset values associated with extraction and depletion $\left(D_{\mathrm{NC}}\right)$

(4) damages from carbon dioxide and particulate emissions are deducted $\left(\mathrm{CO}_{2}\right)$;

(5) divided by the gross national income (GNI)

That can be summed up in the following expression:

$$
A N S=\frac{G N S-D_{\mathrm{K}}+G E E-D_{\mathrm{NC}}-C O_{2}}{G N I}
$$

where GNS are calculated as gross national income less total consumption, plus net transfers. 
If the adjusted net savings of a country are positive, it suggests that the present value of social welfare is increasing. On the contrary, persistently negative adjusted net savings are indicating that the economy is in an unsustainable path.

\section{Determinants of Sustainable Development}

\section{The Role of Institutions and E-Government}

It is recognized that the quality of institutions affects sustainable development (Aidt, 2010; Boos \& Holm-Müller, 2013; Bota-Avram et al., 2018; Sato et al., 2018; Sharma, 2007; United Nations, 2018; Venard, 2013). Better government may contribute to proper resource allocation fostering sustainable development (BotaAvram et al., 2018; Kaufmann et al., 2005; Sato et al., 2018).

In the United Nations General Assembly Resolution 66/2888_ “The Future We Want" the Member States reiterated that good governance, democracy, rule of law and an enabling environment are fundamental for sustainable development, including inclusive economic growth, social development and environmental protection. Nowadays, digital technologies have the potential to transform the conventional way of doing things and ICTs "offer governments an unprecedented opportunity to achieve sustainable development and improve the well-being of their citizens" (United Nations, 2018, xxvii). To the World Bank (2013) "E-Government refers to the use by government agencies of information technologies (such as Wide Area Networks, the Internet, and mobile computing) that have the ability to transform relations with citizens, businesses, and other arms of government". According to the United Nations $(2016,6)$, e-government has turned into a development indicator and "an aspiration in and of itself". E-government is a tool to achieve better government (UNDESA 2001 and Organization for Economic Co-operation and Development (OECD) in United Nations, 2016, 165) and positively influence good governance which is essential to attain sustainable development (Alaaraj \& Ibrahim, 2014; United Nations, 2016). For Von Haldenwang (2004), e-government is not neutral in terms of governance and can, in developing countries, improve administrative capacity and democratic governance.

The e-government has several benefits such as improve the delivery of government services, reduce costs, time savings, promote participation through sharing knowledge between government and citizens, citizen empowerment, improve interactions with business and industry, increase effectiveness and efficiency in all sectors of government and revenue growth (Al-Khateeb et al., 2015; World Bank, 2013) and over and above, political and sociological effects such as transparency, openness and limit corruption (Stanimirovic \& Vintar, 2013; World Bank, 2013).

E-government development is an important factor in rationalizing the public sector and to faster countries development (Stanimirovic \& Vintar, 2013) and has an impact on sustainable development through the economic, social and environmental dimensions. Corsi et al. (2006), in a study prepared for the E-government Unit of European Commission, consider that due to the importance of the public sector 
in European countries, e-government programs can improve economic growth. According to the authors, e-government development increases the efficiency of the public sector, and by improving labour productivity in this sector, the growth of public sector output, the efficiency of public administration and the increase in aggregate demand have a positive effect on economic growth. E-government may also contribute to the social and environment dimensions of sustainability. It can help in the delivery of basic services such as education, health, employment and social welfare and promote more equality in the access to these services. By disseminating information (namely by Open Government Data), governments can alert and help communities to the need to balance between using natural resources and maintaining their quality and availability (United Nations, 2018).

Despite the literature on the effects of e-government on economic growth, studies of its impact on sustainable development assessed by adjusted net savings are to a lesser extent. Dietz et al. (2007) analysed several specific aspects of institution quality (lack of corruption, bureaucracy quality and rule of law) in genuine savings in 115 countries and the results suggest that, through the interaction between resource abundance and corruption, the negative impact of resource abundance in genuine savings could be reduced by improving their performance in controlling corruption. In a panel data of 63 countries, Sato et al. (2018) conclude that better institutions improve not only the level of genuine savings but also stabilize its volatility. Other authors also found a positive relationship between indicators of good governance and adjusted net savings (Boos \& Holm-Müller, 2013; Bota-Avram et al., 2018; Güney, 2017a).

The OECD $(2003,11)$ defines e-government as "the use of information and communications technologies (ICTs), and particularly the Internet, to achieve better government", and considers that e-government is more about governance than about "e". To $\operatorname{OECD}(2003,11)$ "the impact of e-government at the broadest level is simply better governance by enabling better policy outcomes, higher quality services, greater engagement with citizens and by improving other key outputs". E-government has a central role for transformational development in quality, efficiency and effectiveness of governance, resource management and can contribute to good governance (Bala \& Verna, 2018; Heeks, 1999). Although e-governance has the objective of enhancing information and service delivery by public institutions through the use of ICTs, increasing the quality and speed of the services, it also increases democratic participation and accountability (Subramanian, 2012). "E-government can assist governments in going green and backing successful natural resource management, and in addition impel economic growth and further social incorporation of underprivileged and assailable groups" (Nica, 2015, 70). E-government helps to increase the potential of an economy by diffusion of knowledge and information (Majeed \& Malik, 2016). Gustova (2017) evaluates the impact of e-government on economic and social development, using data for 34 European countries during the period 2003-2014. The results provide evidence that e-government impacts positively not only economic growth, but also the Health Index and negatively the under-five mortality rate. These findings support the conviction that the 
adoption of digital technologies by governments leads to significant changes not only in economic performance but also in social development.

Although several studies analyse the impact of indicators of governance in sustainable development, there is no empirical literature on the impact of e-government on adjusted net savings as an indicator of sustainable development.

\section{Other Determinants of Sustainable Development}

Besides the quality of institutions, several other variables are considered in the literature as determinants of sustainable development as economic growth, per capita income, age dependency, urbanization, resource abundance and financial development, among others. Nevertheless, the studies vary in the measure of sustainable development, independent variables included, the sample (panel of developed and/or developing, or only one country) and estimation methods (OLS, random/fixed effects, autoregressive distributed lag model, GMM and IV (2SLS) methods, Johansen test of cointegration and VECM, among others), thus making it difficult to compare the results.

Koirala and Pradhan (2019), using panel data for 12 Asian countries (developing and developed countries) during the period 1990-2014, found that per capita income and financial development are significantly positive determinants of adjusted net savings, but natural resource rents, inflation and time have a negative influence. Dietz et al. (2007), also for a panel data of developing and developed countries (115 countries) over 18 years, found that natural resource abundance (measured by the share of fuel and mineral products in total exports) has a significant negative impact in genuine saving rates in resource-rich countries. Their results also suggest a positive impact of economic growth and some support for the negative impact of age dependency, but per capita national income and urbanization were not statistically significant. Güney (2017b) in a research paper with the objective of studying the impact of population growth in sustainable development (adjusted net savings) for the whole sample of 142 countries found that population growth and youth growth have a significant negative impact on sustainable development, but the growth of the labour force and population with more than 65 years are not significant determinants of sustainable development, although these results are different in developing and developed countries. Furthermore, economic growth, control of corruption and trade openness increase sustainable development, while consumption affects it negatively. Güney (2017a) studied the relationship of governance and sustainable development, and besides the positive effects in the whole sample (and in developing and developed countries), also found that democracy and urbanization promote sustainable development, while population growth impacts it negatively and economic growth is not significant. Pardi et al. (2016) found that, for the member states of the Association of Southeast Asian Nations and Japan, sustainable development was negatively affected by the inflation rate, money supply, non-renewable natural resources extraction and population growth.

For Kenya in the period 1991-2014, Kaimuri and Kosimbei (2017) concluded that real GDP per capita, resource productivity and terms of trade do not have a significant impact on adjusted net savings, but sustainable development (ANS) is 
affected negatively in the long run by household consumption per capita, and in short run by unemployment and energy efficiency.

\section{Methodology}

Sustainable development will be defined as non-declining wealth (Hamilton, 2000; Sato et al. 2018). Wealth $(W)$ includes manufactured capital $(K)$, human capital $(H)$ and natural capital $(N)$ :

$$
W_{\mathrm{t}}=K_{\mathrm{t}}+H_{\mathrm{t}}+N_{\mathrm{t}}
$$

And sustainable development (SD) will be given by

$$
S D=\frac{d W_{\mathrm{t}}}{d t}=\frac{d K_{\mathrm{t}}}{d t}+\frac{d H_{\mathrm{t}}}{d t}+\frac{d N_{\mathrm{t}}}{d t} \geq 0
$$

The empirical investigation on the impact of e-government and other variables in sustainable development is examined for 103 countries in the period 2003 to 2018 , for which all the necessary information was available. The list of the countries included is reported in the Appendix (Table 6). As in previous studies, sustainable development will be proxied by adjusted net savings in percentage of gross national income (ANS). From the adjusted net savings, a binary variable was definedANSbin-to flag when a country has a non-negative ANS:

$$
\operatorname{ANSbin}_{\mathrm{i}}=\left\{\begin{array}{l}
1 \text { if } A N S_{\mathrm{i}} \geq 0 \\
0 \text { if } A N S_{\mathrm{i}}<0
\end{array} \forall i\right.
$$

With this binary variable, a logistic regression model was developed to relate the probability of having non-negative ANS with several key factors for sustainable development.

The logit model is expressed by:

$$
\ln \left(\frac{\mu_{\mathrm{i}}}{1-\mu_{\mathrm{i}}}\right)=\beta_{0}+\beta_{1} E \mathrm{GOV}_{\mathrm{i}}+\sum_{\mathrm{j}} \beta_{\mathrm{j}} X_{\mathrm{j}_{\mathrm{i}}} \forall i
$$

where $\mu_{\mathrm{i}}=P\left(A N \operatorname{Sbin}_{\mathrm{i}}=1\right)=P\left(A N S_{\mathrm{i}} \geq 0\right)$ is the probability of a country $i$ having non-negative ANS and $\frac{\mu_{\mathrm{i}}}{1-\mu_{\mathrm{i}}}$ is the odds ratio in favour of having non-negative ANS, that is, the ratio of the probability of a country having sustainable development to the probability that ANS will be negative. EGOV is electronic government and $X_{\mathrm{j}}$ are the remaining control variables. The choice of the control variables was guided by previous empirical studies on the determinants of sustainable development, discussed in the literature review, namely the economic growth, income per capita, age dependency and natural resource abundance. The model will be estimated for the whole sample and separately for the subsample of developing and transition 
economies. The analysis was not made for developed countries, since almost all the observations had non-negative ANS.

Sustainable development will also be proxied by the HDI to analyse the robustness of the impact of e-government on Sustainable development. HDI is a measure, in a scale of 0 to 1 , of three key dimensions of human development: a long and healthy life, knowledge and a decent standard of living, according to UNDP (2020). The United Nations groups countries in the categories of low (below 0.550), medium (0.550-0.699), high (0.700-0.799) and very high (0.800 and above) human development. From this categorisation, a binary variable was defined-HDIbin - that takes the value 1 if HDI is equal or over 0.699 and 0 otherwise.

E-government (EGOV) is measured by the e-Government Development Index from the United Nations and it is the weighted average of normalized scores on the three most important dimensions of e-government: (1) the Online Service Index, which is the scope and quality of online services quantified, (2) the Telecommunication Infrastructure Index, which measures the status of the development of telecommunication infrastructure; and (3) the Human Capital Index. It ranges from zero to one, where higher scores denote better e-government development (United Nations, 2018).

E-government has been growing rapidly and the 2018 e-government survey (UN, 2018) highlights a persistent positive trend in e-government development. Among the 193 countries analysed in that survey, 40 of them scored very high (with e-Government Development Index between 0.75 and 1), an increase of 11 countries when compared with 2016. The average world e-Government Development Index has been increased from 0.44 in 2010 to 0.55 in 2018 . The countries in the top ten in e-Government Development Index in 2018 are Denmark, Australia, Republic of Korea, United Kingdom, Sweden, Finland, Singapore, New Zealand, France and Japan. Also, the number of countries that have low e-Government Development Index (0-0.25) dropped from 32 in 2016 to 16 countries in 2018. Among the countries with a low e-Government Development Index, 14 countries are African and belong to the group of least developed countries.

It is expected that economic growth indicts an increase in investment resources, contributing to the accumulation of a productive base, and so increases adjusted net savings (Sato et al., 2018). Nevertheless, Güney (2017a) considers that economic growth can affect negatively sustainable development due to increases in environmental pollution, although in a sample of developed and developing countries, the author did not find a significant impact on adjusted net savings but significantly positive in the sample of developed countries.

Per capita national income may contribute positively to sustainable development since higher incomes (as a primary determinant of saving) will increase savings. Per capita income is proxied by gross national income per capita (GNIpc) in constant 2010 USD.

The age structure of the population of the countries can affect savings through the burden of dependency (Hess, 2010). An increase in youth dependency in relation to net producers will require a higher share of income to the social welfare of the children (youth dependency in relation to net producers), which expands consumption expenditures in national income. In the same way, with an increase in the elderly dependency ratio, there will be dissaving and a rise in healthcare expenses (Hess, 
2010). If a large proportion of resources are needed by a relatively less productive part of the population, it is expected that a rise in the age dependency (youth and elderly) will have a negative effect on adjusted net savings. Age dependency was measured by the ratio of dependents-people younger than 15 or older than 64 - to the working-age population (ages 15-64).

Natural resources rents measure the degree to which an economy depends on natural resources to generate income. In some countries, the share of natural resources earnings in GDP are in the form of rents (revenues above the cost of extracting resources), since they are not produced. The supply of these resources is relatively fixed, and so these rents reduce the capital stock, and when they are applied in current consumption instead of being reinvested, those countries are borrowing against the future. So, it is expected that a high share of natural rents in GDP reduces sustainable development. The variable used was total natural resources rents ( $\%$ of GDP) which is the sum of oil rents, natural gas rents, coal rents (hard and soft), mineral rents and forest rents.

Table 1 shows the summary of indicators and measurements for the independent variables used, their data sources and expected sign.

Table 2 reports the descriptive statistics of the variables for the whole sample. During the period under analysis, the highest value for the ANS is observed in Kuwait in 2006, and the lowest in Angola in 2008. Angola reports a systemic problem of sustainable development with an average value of ANS by $-24.6 \%$ in the period 2003-2018, followed by Guinea $(-16.6 \%)$ and Lebanon $(-15.3 \%)$. Singapore has the highest average value in the period $(35.1 \%)$. In the sample, the average level of adjusted net savings is $9.14 \%$.

E-government ranges from 0.946, observed in the Korea Republic in 2014, to the lowest level of development in Guinea in 2013 (0.048). Guinea has the lowest average e-Government Development Index of 0.124. There are countries with e-Government Development Index under 0.30, on average, in the period under analysis, in regions such as Africa (Guinea, Malawi, Madagascar, Cameroon, Angola and Nigeria), but also in some Asian countries (Lao People's Democratic Republic, Pakistan, Bangladesh, Cambodia and Nepal). Poor connectivity, high costs of access and lack of the necessary skills and qualifications, associated with insufficient investments, may prevent governments from benefit from the use of ICTs.

According to the simple regression analysis, it was found that $F(1,1639)=82,932$, with a $p$ value $<0.0001$ for the whole sample, and $F(1,1144)=96,116$ for developing and in transition economies, revealing that the model of e-government is statistically significant in predicting adjusted net savings (Fig. 1). The results of these regressions suggest a positive relation between e-Government Development Index and adjusted net savings although this is especially more remarkable in the case of developing and transition economies, and statistically significant, which suggest not only that e-government can be a relevant variable in explaining sustainable development, but also the impact is higher in the last group of countries. While an increase by 0.1 in e-Government Development Index induces an increase in ANS by 1.29 in the worldwide sample, in developing and transition economies, the same increase in e-government induces an increase in ANS by 2.29. 


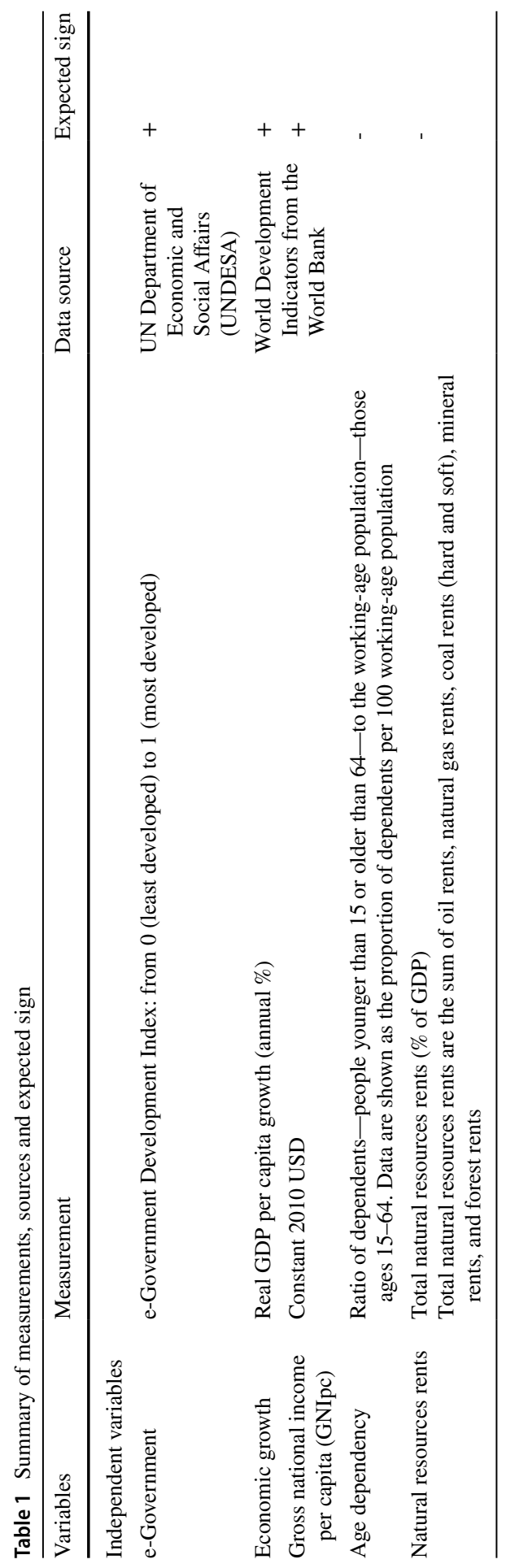


Table 2 Descriptive statistics for the whole sample

\begin{tabular}{llllll}
\hline Variable & Mean & Median & SD & Min & Max \\
\hline Adjusted net savings (ANS) & 9.14 & 8.68 & 10.88 & -42.17 & 42.73 \\
Human Development Index (HDI) & 0.739 & 0.752 & 0.134 & 0.338 & 0.954 \\
E-government (EGOV) & 0.551 & 0.534 & 0.184 & 0.0477 & 0.946 \\
Age dependency & 55.59 & 52.06 & 14.77 & 26.99 & 107.82 \\
Economic growth & 2.64 & 2.54 & 3.60 & -14.56 & 33.00 \\
Natural rents & 5.98 & 1.91 & 9.71 & 0.00019 & 62.05 \\
Gross national income per capita (GNIpc) & $16,444.30$ & $7,353.82$ & $19,568.41$ & 367.95 & $103,039.30$ \\
\hline
\end{tabular}

Almost all of the countries that have a high value of e-Government Development Index (above the 3rd quartile) have positive adjusted net savings, while countries with the lowest levels of e-government development have negative ANS (Fig. 2).

\section{Results and Discussion}

The logit model to be estimated is given in Eq. (6) and the results of the model estimation in Table 3.

$$
\begin{aligned}
\ln \left(\frac{\mu_{\mathrm{i}}}{1-\mu_{\mathrm{i}}}\right)= & \beta_{0}+\beta_{1} \text { EGOV }_{\mathrm{i}}+\beta_{2} \text { Age dependency }_{\mathrm{i}} \\
& +\beta_{3} \text { Economic growth }_{\mathrm{i}}+\beta_{4} \text { Natural rents }_{\mathrm{i}}+\beta_{5} \text { GNIpc }_{\mathrm{i}}
\end{aligned}
$$

The coefficients of the logit model, the odds ratios, the standard errors and $p$ values of the Wald test are shown in Table 3. All the variance inflation factors (VIF) were less than 4 , so all the variables were included in the model since there are no serious problems with multicollinearity. The log-likelihood ratio test, significant at a $1 \%$ level, shows the overall goodness of fit of the model. The Omnibus tests of model coefficients $\left(\chi_{(5)}^{2}=284.566\right.$, with a $\left.\rho<0.001\right)$ and Hosmer and Lemeshow test $\left(\chi_{(8)}^{2}=11.981\right.$, with a $\left.\rho=0.152\right)$ also suggest a good fit for the model. Apart from

a

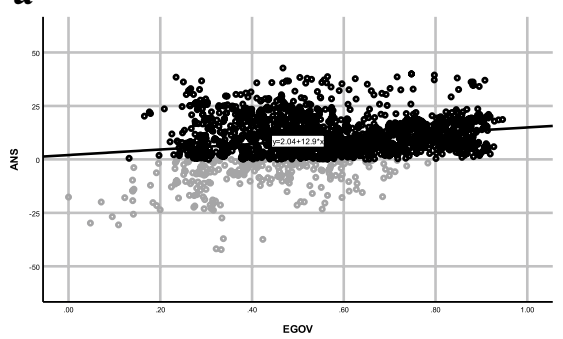

b

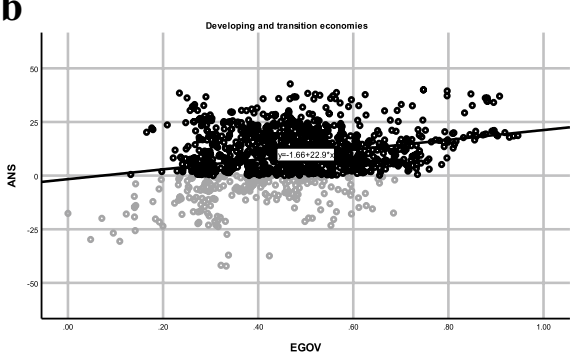

Fig. 1 Scatterplot between e-Government Development Index and adjusted net savings for all countries (a) and for developing and transition economies (b) 


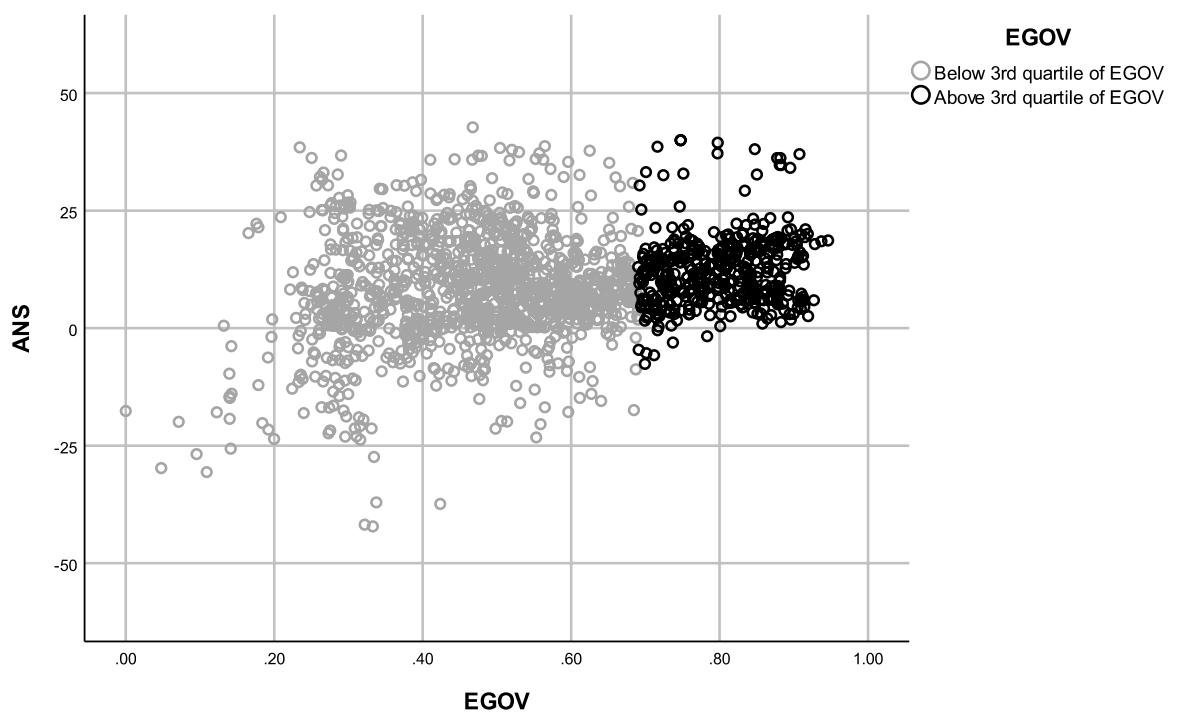

Fig. 2 Scatterplot between e-Government Development Index and adjusted net savings for all countries highlighting the countries in the top $25 \%$ of e-government

this, although the values obtained from pseudo $R^{2} \quad\left(R_{\text {Cox }}^{2}\right.$ \& Snell $=0.164$; $\left.R_{\text {Nagelkerke }}^{2}=0.303 ; R_{\text {MacFadden }}^{2}=0.229\right)$ are moderate, the model correctly classifies the outcome for $88.6 \%$ of the cases. The analysis of the ROC (receiver operating characteristic) curve, with an area under the curve of 0.815 , significantly higher than $0.5(p<0.001)$, reveals that the model has a good discriminating capacity, demonstrating the usefulness of the model for classifying new observations (Fig. 3). The Cook distance found was less than one; therefore, none of the observations can be considered influential.

The Wald test shows that all the explanatory variables are statistically significant at a $1 \%$ significance level (e-government, economic growth, age dependency, natural rents and GNI per capita) in affecting the likelihood of having non-negative ANS.

The results suggest that e-government is an important determinant of the odds of having sustainable development. With an increase of 0.1 in e-Government Development Index, and maintaining the remaining variables constant, it is expected that the odds of having sustainable development increases about 26.52\% $\left(\left(e^{\beta_{\mathrm{i}} 0.1}-1\right) \times 100\right)$

For a unit percentage point increase in age dependency, the expected odds ratio is 0.979795 which means that an increase in one percentage point in age dependency, while maintaining the remaining variables unchanged, decreases the probability of having non-negative ANS by $2.02 \%$. This is similar to the findings of Sato et al. (2018) and Dietz et al. (2007) where this variable is also significant and negative in some of the estimated models.

It is also likely to occur sustainable development if economic growth is higher: a unit percentage point increase in economic growth will increase the probability of 
Table 3 Results of the logit model estimation for the whole sample Logit, using 1587 observations Dependent variable: ANSbin

\begin{tabular}{|c|c|c|c|c|c|c|c|}
\hline & Coefficient $\beta$ & $\begin{array}{l}\text { Odds ratio } \\
e^{\beta}\end{array}$ & Std. error & $z$ & $p$ value & & VIF \\
\hline const & 1.628130 & 5.094339 & 0.725850 & 2.243 & 0.0249 & $* *$ & \\
\hline EGOV & 2.352390 & 10.510660 & 0.820507 & 2.867 & 0.0041 & $* * *$ & 3.535 \\
\hline Age dependency & -0.020412 & 0.979795 & 0.006714 & -3.040 & 0.0024 & $* * *$ & 1.657 \\
\hline $\begin{array}{l}\text { Economic } \\
\text { growth }\end{array}$ & 0.118523 & 1.125833 & 0.025370 & 4.672 & $<0.0001$ & $* * *$ & 1.095 \\
\hline Natural rents & -0.059703 & 0.942044 & 0.007650 & -7.804 & $<0.0001$ & $* * *$ & 1.080 \\
\hline GNIpc & $5.59221 \mathrm{e}-05$ & 1.000056 & $1.23858 \mathrm{e}-05$ & 4.515 & $<0.0001$ & $* * *$ & 2.501 \\
\hline $\begin{array}{l}\text { Mean dependent } \\
\text { var }\end{array}$ & & 0.867675 & S.D. dependent var & & & & 0.338951 \\
\hline $\begin{array}{l}\text { McFadden } \\
R \text {-squared }\end{array}$ & & 0.229425 & Adjusted R-squared & & & & 0.219750 \\
\hline Log-likelihood & & -477.8895 & Akaike criterion & & & & 967.7789 \\
\hline $\begin{array}{l}\text { Schwarz crite- } \\
\text { rion }\end{array}$ & & 999.9965 & Hannan-Quinn & & & & 979.7473 \\
\hline
\end{tabular}

Number of cases 'correctly predicted' $=1404(88.5 \%)$

$f$ (beta' $\mathrm{x})$ at mean of independent vars $=0.339$

Likelihood ratio test: Chi-square $(5)=284.566$ [0.0000]

*The z-statistic is significant at $10 \%$ level, **significant at $5 \%$ and ***significant at $1 \%$

having sustainable development by $12.58 \%$. Dietz et al. (2007) and Sato et al. (2018) similarly found that economic growth increases sustainable development.

For each USD increase in GNI per capita, maintaining the remaining variables constant, it is expected that the odds in favour of having sustainable development will increase by $0.0056 \%$. The results of Koirala and Pradhan (2019) and Dietz et al. (2007) also suggest that an increase in GNI per capita, a primary determinant of savings, will contribute positively to adjusted net savings.

Contrary to the other variables, and as expected, a raise in age structure biased toward the inactive age cohort (less than 15 and more than 64) and more income produced by natural resources leads to the event of non-negative ANS being less likely to occur. The negative impact of natural resource rents is consistent with the resource curse hypothesis and the results of Koirala and Pradhan (2019) and Sato et al. (2018).

According to the results of this model, the predicted probability of having sustainable development increases with the development of e-government (Fig. 4). It is also observable that there are differences between developed economies and developing and transition economies. Therefore, the model will be estimated using only the subsample of developing and transition economies.

In Table 4, the results for the estimation of the model given by Eq. (6) are presented for developing and transition countries. The VIF indicate that data do not have any serious problems of multicollinearity. Concerning the model fitting information, the results of the several measures of $R$ square are still moderate. However, the remaining fitting statistics are fairly good: the Omnibus tests of model coefficients $\left(\chi_{(5)}^{2}=\right.$ 
Fig. 3 ROC curve of the logistic regression model in Table 3

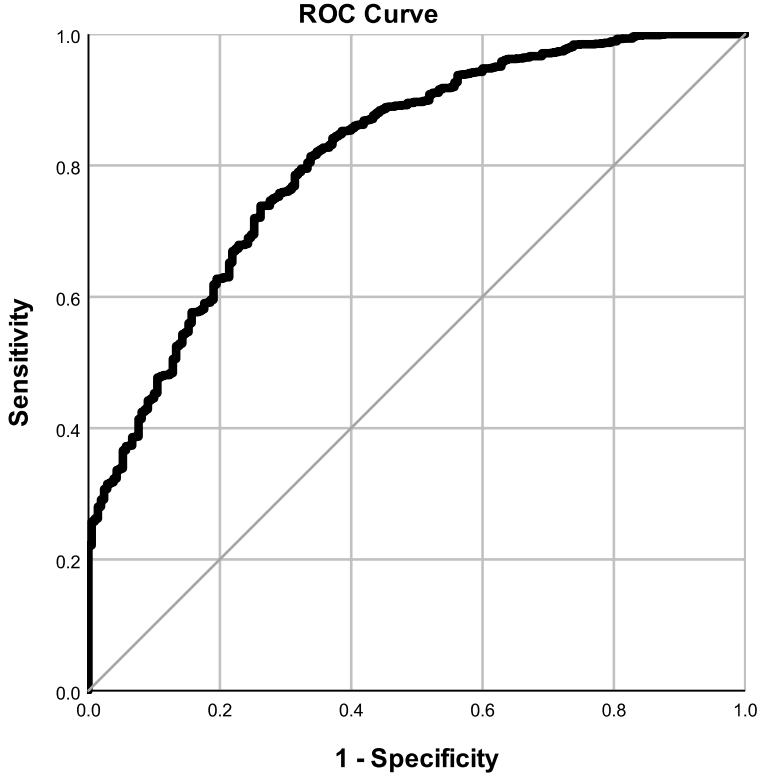

217.023, with a $\rho<0.001)$ and Hosmer and Lemeshow test $\left(\chi_{(8)}^{2}=4.433\right.$, with a $\rho$ $=0.816$ ) indicate that there are no significant differences between observed and predicted values. The power of the logistic model is good since it correctly classifies

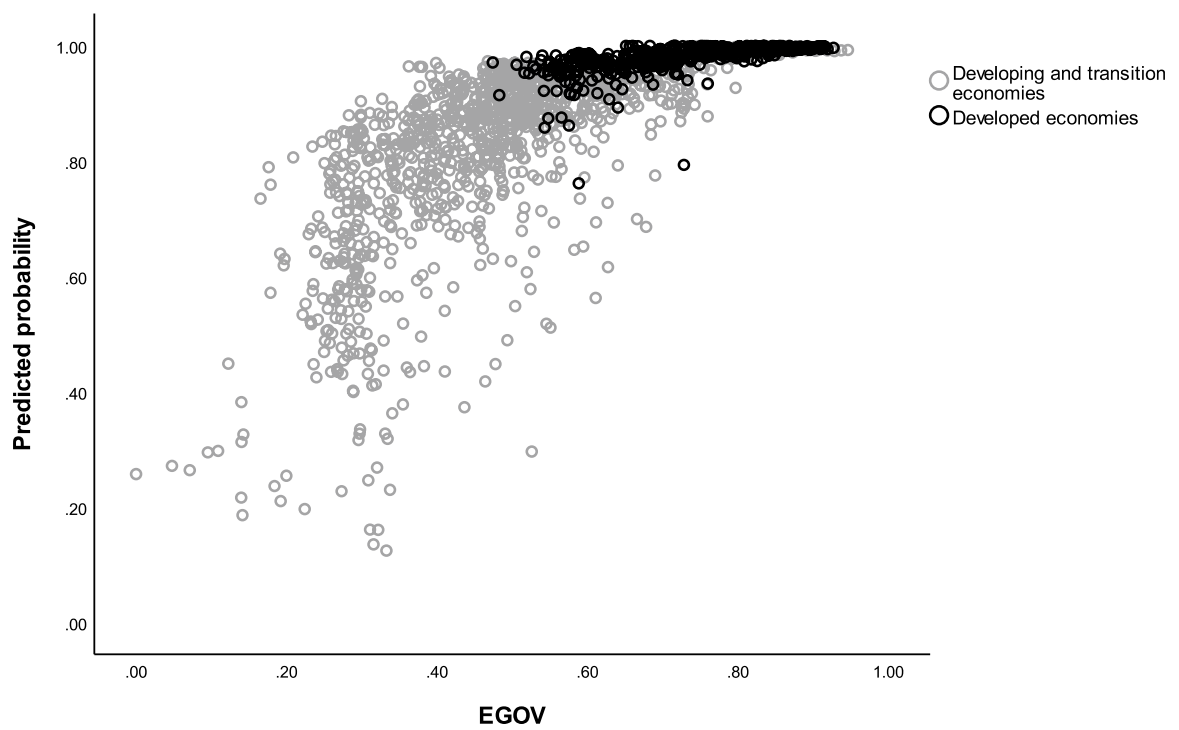

Fig. 4 Scatterplot between the predicted probability of having sustainable development and e-government in the developed economies and in developing and transition economies 
Table 4 Results of the logit model estimation for developing and transition countries Logit, using 1096 observation-dependent variable: ANSbin

\begin{tabular}{|c|c|c|c|c|c|c|c|}
\hline & Coefficient $\beta$ & $\begin{array}{l}\text { Odds ratio } \\
e^{\beta}\end{array}$ & Std. error & $z$ & $p$ value & & VIF \\
\hline const & 0.623007 & 1.864526 & 0.814647 & 0.7648 & 0.4444 & & \\
\hline EGOV & 3.106550 & 22.34383 & 0.932447 & 3.332 & 0.0009 & $* * *$ & 2.651 \\
\hline Age dependency & -0.010138 & 0.989913 & 0.007576 & -1.338 & 0.1808 & & 2.083 \\
\hline Economic growth & 0.136516 & 1.146273 & 0.028893 & 4.725 & $<0.0001$ & $* * *$ & 1.091 \\
\hline Natural rents & -0.083380 & 0.920001 & 0.010481 & -7.956 & $<0.0001$ & $* * *$ & 1.125 \\
\hline GNIpc & 0.000123036 & 1.000123 & $2.49798 \mathrm{e}-05$ & 4.925 & $<0.0001$ & $* * *$ & 1.967 \\
\hline $\begin{array}{l}\text { Mean dependent } \\
\text { var }\end{array}$ & & 0.827555 & $\begin{array}{l}\text { S.D. dependent } \\
\text { var }\end{array}$ & & & & 0.377939 \\
\hline $\begin{array}{l}\text { McFadden } \\
\text { R-squared }\end{array}$ & & 0.215353 & $\begin{array}{l}\text { Adjusted } \\
R \text {-squared }\end{array}$ & & & & 0.203445 \\
\hline Log-likelihood & & -395.3660 & Akaike criterion & & & & 802.7321 \\
\hline Schwarz criterion & & 832.7286 & Hannan-Quinn & & & & 814.0820 \\
\hline
\end{tabular}

Number of cases 'correctly predicted' $=930(84.9 \%)$

$f$ (beta' $\mathrm{x})$ at mean of independent vars $=0.378$

Likelihood ratio test: Chi-square $(5)=217.023$ [0.0000]

*The z-statistic is significant at $10 \%$ level, **significant at $5 \%$ and $* * *$ significant at $1 \%$

$84.9 \%$ of the observations. The area under the ROC curve had a value of $80.2 \%$, reflecting the discriminant power of the model.

In this subsample, it should be emphasised that with a raise by 0.1 units in the e-Government Development Index, it is expected to have the odds of having sustainable development increased by about $36.43 \%$, which is higher than in the whole sample. This means that developing and transition economies can increase the probability of having sustainable development with the digital transformation of governments. Therefore, the findings suggest that these economies could gain more from public investments in technology adoption than developed economies.

The probability of having non-negative ANS also increases more in these countries than in developed economies with raises in economic growth or GNI per capita. Age dependency was not statistically significant at any level. Since these countries are more dependent on natural resources, the increment in natural rents decreases more the odds of having sustainable development.

As previously mentioned, adjusted net savings is an indicator that assesses the changes in capital stocks (produced, human and natural) that will lead to future changes in income. In taking account those forms of capital, it provides information about the country's economic, social and environmental development and is an indicator of sustainability (World Bank, 2006). The Human Development Index, while not including the ecological aspects of sustainability, is also used as an indicator of sustainable development (Kerk \& Manuel, 2008; Witulski \& Dias, 2020). HDI does not directly reflect inequalities in wealth distribution, since it uses national averages for the indicators included; however, as it comprises longevity and knowledge, it indirectly reflects the 
Table 5 Results of the logit model estimation for the total sample and for developing and transition countries dependent variable: HDIbin

\begin{tabular}{|c|c|c|c|c|c|c|}
\hline & \multicolumn{3}{|l|}{ All countries } & \multicolumn{2}{|c|}{$\begin{array}{l}\text { Developing and transition } \\
\text { countries }\end{array}$} & \\
\hline & Coefficient $\beta$ & $p$ value & & Coefficient $\beta$ & $p$ value & \\
\hline EGOV & 8.53031 & 0.000 & $* * *$ & 8.43031 & 0.000 & $* * *$ \\
\hline Age dependency & -0.114130 & 0.000 & $* * *$ & -0.112760 & 0.000 & $* * *$ \\
\hline GNIpc & 0.000601 & 0.000 & $* * *$ & 0.000591 & 0.000 & $* * *$ \\
\hline Mean dependent var & 0.678639 & & & 0.534672 & & \\
\hline Cox \& Snell $R$ square & 0.655 & & & 0.601 & & \\
\hline Log-likelihood & -256.6081 & & & -255.7030 & & \\
\hline Schwarz criterion & 535.3250 & & & 532.4042 & & \\
\hline S.D. dependent var & 0.467146 & & & 0.499024 & & \\
\hline Nagelkerke $R$ square & 0.873 & & & 0.802 & & \\
\hline Akaike criterion & 519.2162 & & & 517.4059 & & \\
\hline Hannan-Quinn & 525.2004 & & & 523.0809 & & \\
\hline Number of observations & 1587 & & & 1096 & & \\
\hline $\begin{array}{l}\text { Number of cases 'correctly } \\
\text { predicted' }\end{array}$ & 1477 & $(93.1 \%)$ & & 987 & $(91.0 \%)$ & \\
\hline
\end{tabular}

$*$ The $z$-statistic is significant at $10 \%$ level, **significant at $5 \%$ and $* * *$ significant at $1 \%$

distribution of resources. In order to check the robustness of the findings, the effects of e-government on sustainable development proxied by the HDI will be analysed. Table 5 reports the results of the analysis of the impact of e-government development on HDI, for the worldwide sample and for developing and transition economies. Regarding the model fitting information, the values of $\chi^{2}$ tests (AIC and Hannan-Quinn criterion, $p$ value $<0.0001)$ indicate good model fit. Moreover, in the worldwide sample, the proportion of correct classification is $93.1 \%$ and in the subsample of developing and transition countries is $91 \%$, with an excellent discrimination evaluated by the area under the ROC curve ( 0.981 and 0.966 , respectively).

Economic growth was not statistically significant as in some previous studies (e.g. Khan et al., 2018), neither natural rents. The positive role of income in human development is observable, highlighted in the literature (Choi et al., 2017). The development of e-government increases the probability of further human development, which reinforces our previous results. From the point of view of human development, it is recognised in the literature that digital government could be a tool of development, since the benefits of public policies could be more efficiently delivered to people, improving the quality of life and poverty reduction (Choi et al., 2017; World Bank, 2006).

To further analyse the relationship between e-government and HDI, scatterplots between the two variables were conducted. The scatterplots in Fig. 5 reveal the strong positive relationship between e-government and HDI. It is also observable for the worldwide sample and for the subsample of developing and transition economies that 

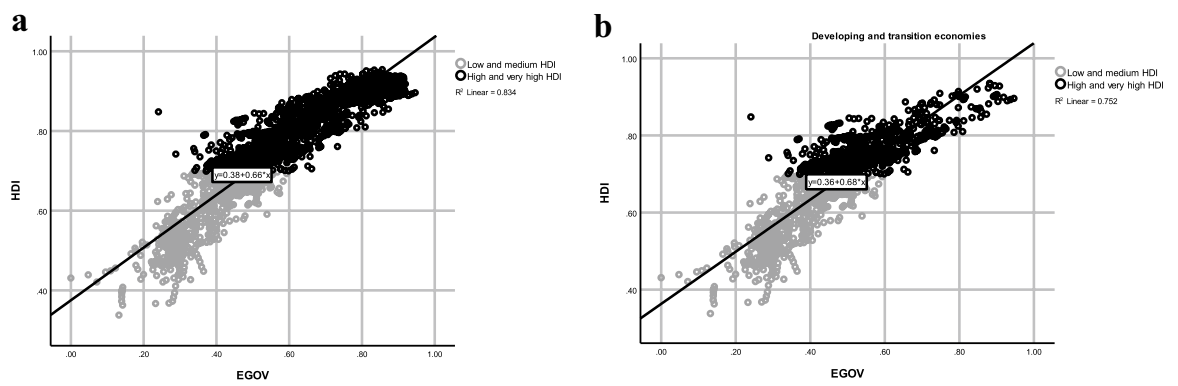

Fig. 5 Scatterplot between e-Government Development Index and Human Development Index for all countries (a) and for developing and transition economies (b)

countries with high or very high levels of HDI are countries with high digital government development.

\section{Conclusions}

Sustainable development is a process of creating national wealth and this depends on the degree of institutional development and improvements in governance, and the digital transformation of governments can provide a more efficient use of resources. This paper highlights the links between e-government and sustainable development and was the first attempt to analyse the effects of e-government in sustainable development in a panel data for 103 countries in the period 2003-2018, using adjusted net savings as an indicator of sustainable development, recommended by the World Bank. Adjusted net savings evaluates the changes in wealth and is an accurate guide for public policy. E-government is the digital transformation of government agencies to operate more efficiently, effectively and transparently, to provide public services with quality, cheaper and faster, and to facilitate citizen and business participation, improving government performance.

The findings of the analysis provide some insights into the literature on sustainable development. It shows evidence that countries with higher e-government development are more likely to have sustainable development since the predicted probability of having non-negative adjusted net savings increases when the e-government is more developed. Furthermore, in developing and transition economies, the odds of increased sustainable development, measured by the adjusting net savings, is higher than in developed countries when e-government development increases. This evidence highlights the importance for developing and transition economies to invest in the use of ICTs by governments. The results also suggest that increases in age dependency and natural resources rents may reduce the likelihood of countries to have sustainable development.

The results of this paper provide information for policymakers of the important role of digital government in achieving sustainable development. While the opportunities that e-government provides are crosscutting to all countries, regardless of the degree of development, developing and transition countries potentially benefit more. Since many 
developing countries face problems of governance and weak institutions, the development of digital government can be a way to promote greater effectiveness and efficiency of public administration, also more equalizer, supporting sustainable development. This reinforces the recognition of the United Nations gives to e-government as an instrument to facilitate integrated policies and public services and to prop up the 2030 Agenda for Sustainable Development (UN, 2016).

Nevertheless, digital governance should not be seen as an end, but as a tool that facilitates and promotes sustainable development. Digital governance is primarily about transforming governance, which must be part of an overall public policy strategy to achieve sustainable development. It also demands a strong commitment by all agents in the society to pursue the welfare of society, and for the strengthening of inclusion.

This paper is focused on non-linear effects since the logit model is a non-linear model that is based on the logistic curve. Nevertheless, in future research, it would be possible to deeply analyse other nonlinear effects of digital governance on sustainable development. Using quantile regression methods could allow to analyse if e-government development could have different effects on the various quantiles of the distribution of adjusted net savings.

E-government has been recognised as a driving force to promote good governance since it combines the internal component of modernization and rationalization of public administration with the external component of the interrelationship between governments and citizens. The year 2020, in the COVID-19 pandemic context, demonstrated the importance of digital government to respond as quickly as possible to the crisis, to make swift policy decisions based on real-time data, to provide online services mainly to those who most need them, to share information and to resolve the socio-economic effects. It has accelerated the digital transformation of governments and was particularly challenging. In future research, it will be important to analyse the effects of e-government in the context of the COVID-19 unprecedented health and economic crisis that implemented a hyper-connected world.

The maximum potential of digital transformation in governments is still far from being achieved, but it should be directed towards transforming governance in order to achieve sustainable development. 


\section{Appendix}

Table 6 List of countries

\begin{tabular}{|c|c|c|c|c|c|c|}
\hline Albania & Brunei Darussalam & Egypt & Israel & Malawi & Pakistan & Sri Lanka \\
\hline Angola & Bulgaria & El Salvador & Italy & Malaysia & Panama & Sweden \\
\hline Argentina & Cambodia & Estonia & Jamaica & Mauritius & Paraguay & Switzerland \\
\hline Armenia & Cameroon & Eswatini & Japan & Mexico & Peru & Tanzania \\
\hline Australia & Canada & Finland & Jordan & Mongolia & Philippines & Thailand \\
\hline Azerbaijan & Chile & France & Kazakhstan & Morocco & Poland & Tunisia \\
\hline Bahamas & China & Georgia & Kenya & Namibia & Portugal & Turkey \\
\hline Bahrain & Colombia & Germany & Korea, Rep & Nepal & Romania & Uganda \\
\hline Bangladesh & Costa Rica & Ghana & Kuwait & Netherlands & Russian Federation & Ukraine \\
\hline Belarus & Croatia & Greece & Kyrgyz Rep & New Zealand & Saudi Arabia & $\begin{array}{l}\text { United } \\
\text { Kingdom }\end{array}$ \\
\hline Belgium & Cyprus & Guatemala & Lao PDR & Nicaragua & Singapore & $\begin{array}{l}\text { United } \\
\text { States }\end{array}$ \\
\hline Belize & Czech Republic & Guinea & Latvia & Nigeria & Slovak Republic & Uruguay \\
\hline Bolivia & Denmark & Hungary & Lebanon & North Macedonia & Slovenia & Vietnam \\
\hline Botswana & Dominican Rep & India & Luxembourg & Norway & South Africa & \\
\hline Brazil & Ecuador & Indonesia & Madagascar & Oman & Spain & \\
\hline
\end{tabular}

\section{References}

Acemoglu, D., \& Robinson, J. (2012). Why nations fail: The origins of power, prosperity, and poverty. New York: Crown Publishers.

Adjei-Bamfo, P., Maloreh-Nyamekye, T., \& Ahenkan, A. (2019). The role of e-government in sustainable public procurement in developing countries: A systematic literature review. Resources, Conservation \& Recycling, 142, 189-203. https://doi.org/10.1016/j.resconrec.2018.12.001.

Aidt, T. (2010). Corruption and sustainable development. In S. Rose-Ackerman \& T. Soreide (Eds.), International handbook on the economics of corruption (Vol. 2, pp. 3-51). Cheltenham, UK: Eduard Elgar Publishing.

Alaaraj, H., \& Ibrahim, F. (2014). The influence of e-government practices on good governance from the perspective of public in Lebanon. Journal of Public Administration and Governance, 4(3), 171-185. https://doi.org/10.5296/jpag.v4i3.6405.

Al-Khateeb, A., Faloudah, A., Bahumayd, M., \& Zafa, A. (2015). E-Government Strategy and its impact on Economic Development of the Nation: A Case Study of the KSA. International Advanced Research Journal in Science, Engineering and Technology, 2(5), 105-110.https://doi. org/10.17148/IARJSET.2015.252

Arrow, K., Dasgupta, P., \& Mäler, K. G. (2003). Evaluating projects and assessing sustainable development in imperfect economies. Environmental and Resource Economics, 26(4), 647-685. https://doi.org/10.1023/B:EARE.0000007353.78828.98.

Bala, M., \& Verna, D. (2018). Governance to good governance through e-Governance: A critical review of concept, model, initiatives \& challenges in India. International Journal of Management, IT \& Engineering, 8(10), 244-269. 
Bawazir, S. (2006). The key factors of successful sustainable development: e-Government in Saudi Arabia as an example. In The18th National Computer Conference 2006, Riyadh, 1-6.

Boos, A. (2015). Genuine savings as an indicator for "Weak" sustainability: Critical survey and possible ways forward in practical measuring. Sustainability, 7, 4146-4182. https://doi.org/10.3390/su7044146.

Boos, A., \& Holm-Müller, K. (2013). The relationship between the resource curse and Genuine Savings: Empirical evidence. Journal of Sustainable Development, 6(6), 59-72. https://doi.org/10.5539/jsd. v6n6p59.

Bota-Avram, C., Grosanu, A., Rachisan, P.-R., \& Gavriletea, M. D. (2018). The bidirectional causality between country-level governance, economic growth and sustainable development: A cross-country data analysis. Sustainability, 10(2), 1-24. https://doi.org/10.3390/su10020502.

Brand, F. (2009). Critical natural capital revisited: Ecological resilience and sustainable development. Ecological Economics, 68, 605-612. https://doi.org/10.1016/j.ecolecon.2008.09.013.

Chiesura, A., \& De Groot, R. (2003). Critical natural capital: a socio-cultural perspective. Ecological Economics, 44, 219-231. https://doi.org/10.1016/S0921-8009(02)00275-6.

Choi, H., Park, M., \& Rho, J. (2017). Two-dimensional approach to governmental excellence for human development in developing countries: Combining policies and institutions with e-government. Government Information Quarterly, 34(2), 340-353. https://doi.org/10.1016/j.giq.2017.03.002.

Corojan, A., \& Criado, J. (2012). E-government for transparency, anti-corruption, and accountability: challenges and opportunities for Central American countries. In K. Bwalya \& S. Zulu (Eds.), Handbook of research one-government in emerging economies: adoption, e-participation, and legal frameworks (pp. 328-350). Hershey: IGI Global. https://doi.org/10.4018/978-1-4666-0324-0.

Corsi, L., Gumina, A., D’ Ippoliti, C., Battisti, M. (2006). eGovernment economics project (eGEP). eGovernment Unit, DG Information Society and Media, European Commission.

De Groot, R., Van der Perk, J., Chiesura, A., \& van Vliet, A. (2003). Importance and threat as determining factors for criticality of natural capital. Ecological Economics, 44, 187-204. https://doi.org/10.1016/ S0921-8009(02)00273-2.

Dietz, S., \& Neumayer, E. (2007). Weak and strong sustainability in the SEEA: Concepts and measurement. Ecological Economics, 61(4), 617-626. https://doi.org/10.1016/j.ecolecon.2006.09.007.

Dietz, S., Neumayer, E., \& Soysa, I. (2007). Corruption, the resource curse and genuine saving. Environment and Development Economics, 12(1), 33-53. https://doi.org/10.1017/S1355770X06003378.

Dwivedi, Y., Weerakkody, V., \& Williams, M. (2009). Guest editorial: From implementation to adoption: Challenges to successful e-government diffusion. Government Information Quarterly, 26, 3-4. https://doi.org/10.1016/j.giq.2008.09.001.

Ekins, P., Simon, S., Deutsch, L., Folke, C., \& De Groot, R. (2003). A framework for the practical application of the concepts of critical natural capital and strong sustainability. Ecological Economics, 44, 165-185. https://doi.org/10.1016/S0921-8009(02)00272-0.

Elbahnasawy, N. (2014). E-Government, internet adoption, and corruption: An empirical investigation. World Development, 57, 114-126. https://doi.org/10.1016/j.worlddev.2013.12.005.

Everett, G., \& Wilks, A. (1999). The World Bank's Genuine Savings indicator: A useful measure of sustainability? Bretton Woods Project. Working to Reform the World Bank and IMF. 1999. http:// www.brettonwoodsproject.org/topic/environment/gensavings.pdf. Accessed 7 February 2019.

Gautam, A., Jain, S., \& Gautam, I. (2017). E governance: a potent tool for effective governance. International Journal of Science Technology and Management, 6(2), 503-516.

Güney, T. (2017a). Governance and sustainable development: How effective is governance? The Journal of International Trade \& Economic Development, 23(6), 316-335. https://doi.org/10.1080/09638199. 2016.1249391.

Güney, T. (2017b). Population growth and sustainable development in developed-developing countries: An IV(2SLS) approach. The Journal of Faculty of Economics and Administrative Sciences, 22(4), 1255-1277.

Gustova, D. (2017). The impact of e-government strategy on economic growth and social development (Master dissertation). https://repositorio.iscte-iul.pt/bitstream/10071/15809/1/daria_gustova_diss_ mestrado.pdf. Accessed 8 January 2020.

Hamilton, K. (2000). Genuine Saving as a Sustainability Indicator. Environment Department Papers, 77 , World Bank.

Hanley, N., Dupuy, L., \& McLaughlin, E. (2015). Genuine savings and sustainability. Journal of Economic Surveys, 29(4), 779-806. https://doi.org/10.1111/joes.12120.

Hardi, P., Barg, S., Hodge, T., \& Pinter, L. (1997). Measuring sustainable development: Review of current practice. Ottawa, Canada: Industry Canada. 
Hartwick, J. (1977). Intergenerational equity and the investing of rents from exhaustible resources. American Economic Review, 67(5), 972-974.

Hartwick, J. (1990). Natural resources, national accounting and economic depreciation. Journal of Public Economics, 43(3), 291-304. https://doi.org/10.1016/0047-2727(90)90002-Y.

Heeks, R. (1999). Reinventing government in the information age: International practice in IT-enabled public sector reform. London: Routledge. https://doi.org/10.4324/9780203204962.

Hess, P. (2010). Determinants of the adjusted net saving rate in developing economies. International Review of Applied Economics, 24(5), 591-608. https://doi.org/10.1080/02692170903426070.

Kaimuri, B., \& Kosimbei, G. (2017). Determinants of sustainable development in Kenya. Journal of Economics and Sustainable Development, 8(2), 17-36.

Kaufmann, D., Kraay, A., \& Mastruzzi, M. (2005). Governance matters IV: Governance indicators for 1996-2004. Washington, DC: World Bank.

Khan, F. N., \& Majeed, M. T. (2019). ICT and E-government as the Sources of Economic Growth in Information Age: Empirical Evidence from South Asian Economies. South Asian Studies - A Research Journal of South Asian Studies, 34(1), 227-249.

Khan, N., Ju, Y., \& Hassan, S. (2018). Modeling the impact of economic growth and terrorism on the human development index: collecting evidence from Pakistan. Environmental Science and Pollution Research, 25, 34661-34673. https://doi.org/10.1007/s11356-018-3275-5.

Klitgaard, R. (1988). Controlling corruption. Berkeley: University of California Press.

Koirala, B., \& Pradhan, G. (2019). Determinants of sustainable development: Evidence from 12 Asian countries. Sustainable Development, 1-7. https://doi.org/10.1002/sd.1963.

Majeed, M., \& Malik, A. (2016). E-government, financial development and economic growth. Pakistan Journal of Applied Economics, 26(2), 107-128.

Neumayer, E. (2012). Human development and sustainability. Journal of Human Development and Capabilities, 13(4), 561-579.

Neumayer, E. (2013). Weak versus strong sustainability: exploring the limits of two opposing paradigms. Northampton: Edward Elgar. https://doi.org/10.4337/9781781007082.

Nica, E. (2015). Sustainable development and citizen-centric e-government services. Economics, Management \& Financial Markets, 10(3), 69-74.

Noël, J.-F., \& O’Connor, M. (1998). Strong sustainability and critical natural capital. In S. Faucheux \& M. O'Connor (Eds.), Valuation for Sustainable Development: Methods and Policy Indicators (pp. 75-99). Cheltenham, UK: Edward Elgar Publisher.

Organization for Economic Co-operation and Development (OECD). (2003). The e-government imperative. Paris: OECD.

Pardi, F., Salleh, A., \& Nawi, A. (2015). Determinants of Sustainable Development in Malaysia: A VECM Approach of Short-Run and Long-Run Relationships. American Journal of Economics, 5(2): 269-277. https://doi.org/10.5923/c.economics.201501.35.

Pardi, F., Nawi, A., \& Salleh, A. (2016). Determining factors toward a sustainable development path in selected ASEAN countries and Japan - Evidence from panel data analysis. International Journal of Business and Information, 11(2), 125-146.

Pearce, D. W., Markandya, A., \& Barbier, E. (1989). Blueprint for a green economy. London: Earthscan Publications.

Pelenc, J., Ballet, J., \& Dedeurwaerder. (2015). Weak sustainability versus Strong sustainability. https:// sustainabledevelopment.un.org/content/documents/6569122-Pelenc-Weak\%20Sustainability\% 20versus\%20Strong\%20Sustainability.pdf. Accessed 12 December 2019.

Qasim, M., \& Grimes, A. (2018). Sustainable economic policy and well-being: The relationship between adjusted net savings and subjective well-being. Motu Working Paper 18-06. Wellington, New Zealand: Motu Economic and Public Policy Research.

Rutherford, I. (1997). Use of models to link indicators of sustainable development. In B. Moldan \& S. Bilharz (Eds.), Sustainability Indicators: Report of the project on indicators of sustainable development. Chichester: John Wiley \& Sons Ltd.

Sato, M., Samreth, S., \& Sasaki, K. (2018). The impact of institutional factors on the performance of genuine savings. International Journal of Sustainable Development and World Ecology, 25(1), 56-68. https://doi.org/10.1080/13504509.2017.1289990.

Sharma, S. (2007). Democracy, good governance and economic development. Taiwan Journal of Democracy, 3(1), 29-62. https://doi.org/10.29654/TJD.200707.0002. 
Srivastava, S. C., Teo, T. S. H., \& Devaraj, S. (2016). You can't bribe a computer: Dealing with the societal challenge of corruption through ICT. MIS Quarterly, 40(2), 511-526. https://doi. org/10.25300/MISQ/2016/40.2.14.

Stanimirovic, D., \& Vintar, M. (2013). Conceptualization of an integrated indicator model for the evaluation of e-government policies. Electronic Journal of e-Government, 11(1), 293-307.

Subramanian, C. (2012). E-governance: A key to good governance in India. International Journal of Recent Scientific Research, 3(5), 305-308.

Sunday, O. (2014). E-governance: An imperative for sustainable grass root development in Nigeria. Journal of Public Administration and Policy Research, 6(4), 77-89. https://doi.org/10.5897/JPAPR2013.0264.

United Nations. (2016). United Nations e-Government Survey 2016 - Gearing e-government to support transformation towards sustainable and resilient societies. New York: United Nations.

United Nations. (2018). United Nations e-Government Survey 2018 - E-government in support of sustainable development. New York: United Nations.

United Nations World Commission on Environment and Development Sustainable. (1987). Our common future: World Commission on Environment and Development. Oxford: Oxford University Press.

UNDP (2020). Human Development report 2020. The next frontier - Human development and the Anthropocene. New York: United Nations.

Uwasu, M., \& Yabar, H. (2011). Assessment of sustainable development based on capital approach. Ecological Indicators, 11, 348-352. https://doi.org/10.1016/j.ecolind.2010.06.002.

Van Bellen, H. (2010). As dimensões do desenvolvimento: Um estudo exploratório sob a perspectiva das ferramentas de avaliação. Revista de Ciências da Administração, 12(27), 143-168.

Van de Kerk, G., \& Manuel, A. (2008). A comprehensive index for a sustainable society: The SSI the Sustainable Society Index. Ecological Economics, 66(2-3), 228-242. https://doi.org/10.1016/j. ecolecon.2008.01.029.

Van der Ploeg, F. (2011). Natural resources: Curse or blessing? Journal of Eonomic Literature, 49(2), 366-420. https://doi.org/10.1257/jel.49.2.366.

Venard, B. (2013). Institutions, corruption and sustainable development. Economics Bulletin, 33(4), 2545-2562.

Von Haldenwang, C. (2004). Electronic government (E-Government) and development. The European Journal of Development Research, 16(2), 417-432. https://doi.org/10.1080/0957881042000220886.

Witulski, N., \& Dias, J. (2020). The Sustainable Society Index: Its reliability and validity. Ecological Indicators, 114, 106190. https://doi.org/10.1016/j.ecolind.2020.106190.

World Bank. (2006). Where is the wealth of the nations? Measuring capital for the 21st century. Washington, DC: World Bank.

World Bank (2012). Beyond GDP - Measuring progress, true wealth, and the well-being of the nations. https:// ec.europa.eu/environment/beyond_gdp/download/factsheets/bgdp-ve-ans.pdf.. Accessed 1 July 2019.

World Bank (2013). Egovernment. https://www.worldbank.org/en/webarchives/archive?url=https\% $3 \mathrm{~A} \% 2 \mathrm{~F} \% 2 \mathrm{Fweb}$.worldbank.org $\% 2$ Farchive $\% 2$ Fwebsite $01358 \% 2 \mathrm{FWEB} \% 2 \mathrm{~F} 0$ _- CON-7. HTM\%3FcontentMDK\%3D20507153\%26contTypePK\%3D217265\%26folderPK\%3D265250\% 26sitePK\%3D702479\%26callCR\%3Dtrue\%26menuPK\%3D702592\%26the SitePK\% 3D702586\&mdk=23350751. Accessed 5 June 2019.

World Bank (2020). World Development Indicators. Adjusted Net Savings. https://databank.worldbank. org/reports.aspx?source=World-Development-Indicators Accessed 5 january 2020.

Publisher's Note Springer Nature remains neutral with regard to jurisdictional claims in published maps and institutional affiliations. 


\section{Authors and Affiliations}

\section{Conceição Castro $^{1}\left(\mathbb{0} \cdot\right.$ Cristina Lopes $^{2} \oplus$}

1 Department of Economics, Porto Accounting and Business School, CEOS.

PP, ISCAP, Polytechnic Institute of Porto, CEPESE, Rua Jaime Lopes Amorim,

4465-004 S. Mamede de Infesta, Portugal

2 Department of Mathematics, Porto Accounting and Business School, CEOS.PP, ISCAP, Polytechnic Institute of Porto, Rua Jaime Lopes Amorim, 4465-004 S. Mamede de Infesta, Portugal 